\title{
Rearing method of Oryzaephilus surinamensis (L.) (Coleoptera, Silvanidae) on various wheat grain granulometry ${ }^{1}$
}

\author{
Helenara dos Santos Beckel ${ }^{2}$, Irineu Lorini ${ }^{3}$ \& Sonia M. N. Lazzari ${ }^{4}$
}

${ }^{1}$ Contribuição número 1727 do Departamento de Zoologia, Universidade Federal do Paraná. Parte da tese de Doutorado em CiênciasEntomologia do $1^{\circ}$ autor, Convênio Embrapa Trigo - UFPR.

${ }^{2}$ R. Cel. Miranda, 651/603, 99025-050. Passo Fundo-RS. helenara@via-rs.net. Bolsista CNPq

${ }^{3}$ Centro Nacional de Pesquisa de Trigo. Caixa Postal 451, 99001-970 Passo Fundo-RS. ilorini@cnpt.embrapa.br

${ }^{4}$ Departamento de Zoologia, Universidade Federal do Paraná. Caixa Postal 19020, 81531-980 Curitiba-PR. lazzari@ufpr.br. Bolsista CNPq

\begin{abstract}
Rearing method of Oryzaephilus surinamensis (L.) (Coleoptera, Silvanidae) on various wheat grain granulometry. Oryzaephilus surinamensis is one of most common insect pest of grains and a variety of stored products, and has been found in high numbers in almost all storage facilities. However, laboratory mass rearing of this insect for bioassays is not a simple task, mainly because of its feeding behavior, small size, and high mobility. Thus, the aim of this work was to develop a simple and efficient laboratory rearing method for $O$. surinamensis, using wheat kernels milled into different granulometry to obtain large number and standardized population at different life stages for bioassays. The adults were collected from storage grain facilities in the southern region of Brazil and 100 specimens were placed inside glass jars with wheat kernels milled at different grades and kept at $25 \pm 0.5^{\circ} \mathrm{C}$ and $65 \pm 5 \%$ relative humidity. The insects were allowed to copulate and lay eggs for 10 days and then removed. The number of eggs, larvae, and pupae was counted at five-day intervals; longevity of the second generation adults was evaluated. The kernels milled at grade 20 were the best medium for offspring production: $89 \%$ of eggs by the $5^{\text {th }}$ day; $30.5 \%$ larvae by the $10^{\text {th }}$ day; $43 \%$ pupae by the $30^{\text {th }}$ day and $63.4 \%$ adults at the 46 th day. The adults survived up to 450 days. Culturing $O$. surinamensis under the described conditions, transferring the parental adults by the $10^{\text {th }}$ day after infestation and replacing the media when population builds up will produce enough insects of each stage for various laboratory bioassays.
\end{abstract}

KEYWORDS. Insect mass rearing; biological cycle; stored wheat; sawtoothed grain beetle.

\begin{abstract}
RESUMO. Método de criação de Oryzaephilus surinamensis (L.) (Coleoptera, Silvanidae) em trigo de diversas granulometrias. Oryzaephilus surinamensis é uma das espécies de insetos-praga mais comuns em grãos e outros produtos armazenados, e tem ocorrido em grandes populações em praticamente todas as unidades de armazenamento de grãos. Contudo, a criação massal deste inseto, em laboratório, para bioensaios diversos, não tem sido uma tarefa simples, em função de seu comportamento alimentar, tamanho reduzido e alta mobilidade. Assim, o objetivo deste trabalho foi desenvolver um método simples e eficiente para a criação de $O$. surinamensis, usando grãos de trigo moídos a diversas granulometrias para obter grandes populações e estágios padronizados para bioensaios. Insetos adultos foram coletados em diversos armazéns na região sul do Brasil; 100 espécimes foram colocados em frascos de vidro, com grãos de trigo moído a diferentes graus, mantidos a $25 \pm 0.5^{\circ} \mathrm{C}$ e $65 \pm 5 \%$ de umidade relativa. Os insetos foram mantidos por 10 dias para cópula e postura dos ovos, sendo então removidos. Ovos, larvas e pupas foram contados a intervalos de cinco dias; a longevidade dos adultos da segunda geração foi avaliada. Os grãos moídos a grau 20 representaram o melhor meio para a produção de progênie: $89 \%$ dos ovos foram produzidos no $5^{\circ}$ dia; $30,5 \%$ das larvas no $10^{\circ} ; 43 \%$ das pupas no $30^{\circ}$ e aproximadamente $63 \%$ dos adultos no $46^{\circ}$. Os adultos sobreviveram até 450 dias. A criação de $O$. surinamensis, nas condições descritas e transferindo os adultos após 10 dias e repondo o meio quando a população aumenta muito, produzirá um número de insetos de cada estágio suficiente para diversos bioensaios de laboratório.
\end{abstract}

PALAVRAS-CHAVE. Criação massal de insetos; ciclo de vida; praga de trigo armazenado; besourinho-dos-cereais.

The sawtoothed grain beetle, Oryzaephilus surinamensis (Linnaeus, 1758) (Coleoptera, Silvanidae), is one of the most common grain and stored product insect pest worldwide (Champ \& Dyte 1976). It is a secondary pest in stored grain due to its inability to damage the whole grain; however, its status has changed due mainly to the mechanical damage during harvesting and drying, which results in broken and damaged grain going to storage facilities, where this pest species will build up and cause very high infestation problems (Mathlein 1971; Howe 1973; Pricket et al. 1990). Adults and larvae also attack flours, breakfast cereals, feed, copra, nuts and dried fruits, especially because of their ability as cosmopolitan invaders of packaged food (Highland 1991;
Mowery et al. 2002). In Brazil, the sawtoothed grain beetle infests all stored grain facilities causing deterioration and losses in grain quantity and quality (Lorini 2005).

The sawtoothed grain beetle is a very small insect which has the ability to hide in many places in storage facilities, making it difficult to be controlled by insecticides, and it has built up resistance to several insecticides (Greening et al. 1974; Heather \& Wilson 1983; Wallbank \& Collins 2003).

Although the biology of $O$. surinamensis has been studied by many authors (Howe 1956, 1965; Fleming 1988; Collins et al. 1989; Jacob \& Fleming 1989; Mason 1996), the rearing process to get good production of offspring is still a challenge because of the small size of the insect and its high mobility. 
Oryzaephilus surinamensis prefers cereal food than oil seeds to feed on (Sinha 1971; LeCato \& McCray 1973; Nakajima et al. 1996). Fraenkel \& Blewett (1943) discussed that this species requires good balance of carbohydrates in its diet and does not grow well in whole grain. However, it grows faster on broken and milled grain, what increases the population rapidly (Turney 1957). LeCato \& McCray (1973) tried to grow $O$. surinamensis on oil seeds without success. The diet on peanuts caused high adult mortality, and the few survivors had very long life cycles, but low progeny production. Results from Thomas \& Shepard (1940) showed that milled nuts caused high larval mortality. These authors discussed that the nuts are less hygroscopic than oats due to its oil seed content, and the longer life cycle of $O$. surinamensis depends on the hygroscopic ability of the food source. Flinn \& Friesen (2007) described two culture media for the sawtoothed grain beetle using whole wheat, crimped wheat, wheat germ and brewers yeast for the first one, and wheat flour, wheat germ and brewers yeast for the second medium. They also described how to handle and keep the media.

Weston \& Rattlingourd (2000) showed an increase of progeny production of $O$. surinamensis on maize previously infested for 6-mo with Sitotroga cerealella (Olivier, 1819) (Lepidoptera, Gelechiidae). They concluded that the damage caused by primary colonizers increases dramatically the potential for population growth of the secondary colonizers, oviposition is stimulated cannibalism reduced because refugia provided by tunneling.

The aims of this work were to develop a laboratory rearing method for $O$. surinamensis using different wheat granulometry to produce large and standardized population numbers for bioassays; to determine the best period of time to harvest specimens of each stage and determine the longevity of $O$. surinamensis on the best selected diet.

\section{MATERIALAND METHODS}

Adults of $O$. surinamensis were collected in wheat grain from storage units in Passo Fundo, in the state of Rio Grande do Sul, Brazil. The insects, designated as OS1 strain, were kept on the grains, at room temperature, in the Entomology Laboratory of Embrapa Trigo, until the experiments started.

Wheat kernels were disinfested in an oven at $60^{\circ} \mathrm{C}$ for one hour and left for three hours to cool down, then milled to grades 5, 9, 11 and 20, using a Buhler-Miag, MLI 2041988 mill; plus a treatment consisting of whole wheat grain. The experiment was set-up on randomized plots, with four replicates for each treatment. Each glass jar was filled with $80 \mathrm{~g}$ of the specific diet and sealed with arboseal and filter paper as a lid. Adults were sifted (mesh 30, aperture $600 \mathrm{~mm}$ ) out from the stock culture, and 100 individuals (sex and age not determined) were placed in each jar (replicate). The jars were kept in a room at $25 \pm 0.5^{\circ} \mathrm{C}$ and $65 \pm 5 \%$ relative humidity (RH). The insects were allowed to copulate and lay eggs for ten days, and then removed.

The number of eggs, larvae, and pupae were counted at five-day intervals, until all adults from the second generation emerged. The medium was sifted, every five days, to remove the adults, which were placed in a new jar containing the same diet and under the same rearing conditions to determine the longevity period. The average numbers of adults obtained and observed for longevity were: 126, 129, 144, 200, and 8, respectively, for grain grade, 5, 9, 11, 20, and whole grain. The number of adults was counted at twenty-day intervals removing the dead adults. The adults were placed in new jars containing the same type of diet to avoid generation overlap.

Data were analyzed using ANOVA, and comparisons between means were done by Tukey test $(p>0.05)$.

\section{RESULTS AND DISCUSSION}

Rearing Method. The diet of wheat milled to grade 20 produced the highest number of offspring, averaging 199.5 adults, which was statistically superior to the other treatments, except for the grade 11, which produced an average of 143.75 adults (Table I).

On whole wheat grain, the mean number of adults was 7.75 (Table I), similar to the number obtained by Turney (1957), showing that this insect species does not grow well in whole grain, whereas the milled grain favors a rapid population increase. Also, LeCato \& McCray (1973) showed that $O$. surinamensis moves easier on milled grain, which may stimulate the females to lay eggs.

Table I. Mean number of eggs, larvae, pupae, and adults of Oryzaephilus surinamensis reared on wheat kernels milled at different granulometry, at $25 \pm 0.5^{\circ} \mathrm{C}$ and $65 \pm 5 \% \mathrm{RH}$.

\begin{tabular}{lcrrr}
\hline Diet & $\mathrm{n}^{\text {o }}$ of eggs & $\mathrm{n}^{\circ}$ of larvae & $\mathrm{n}^{\circ}$ of pupae & $\mathrm{n}^{\circ}$ of adults \\
\hline Grade 5 & $44.5 \mathrm{bc}$ & $172.25 \mathrm{~b}$ & $76.00 \mathrm{c}$ & $126.25 \mathrm{~b}$ \\
Grade 9 & $61.4 \mathrm{~b}$ & $267.75 \mathrm{~b}$ & $103.75 \mathrm{~b}$ & $128.75 \mathrm{~b}$ \\
Grade 11 & $29.9 \mathrm{bc}$ & $248.50 \mathrm{~b}$ & $129.00 \mathrm{~b}$ & $143.75 \mathrm{ab}$ \\
Grade 20 & $352.1 \mathrm{a}$ & $571.75 \mathrm{a}$ & $215.00 \mathrm{a}$ & $199.50 \mathrm{a}$ \\
Whole grain & $17.2 \mathrm{c}$ & $13.75 \mathrm{c}$ & $8.00 \mathrm{~d}$ & $7.75 \mathrm{c}$ \\
\hline
\end{tabular}

Mean numbers followed by the same letter, within the same column, are not significantly different $(\mathrm{P}>0.05)$ by Tukey test.

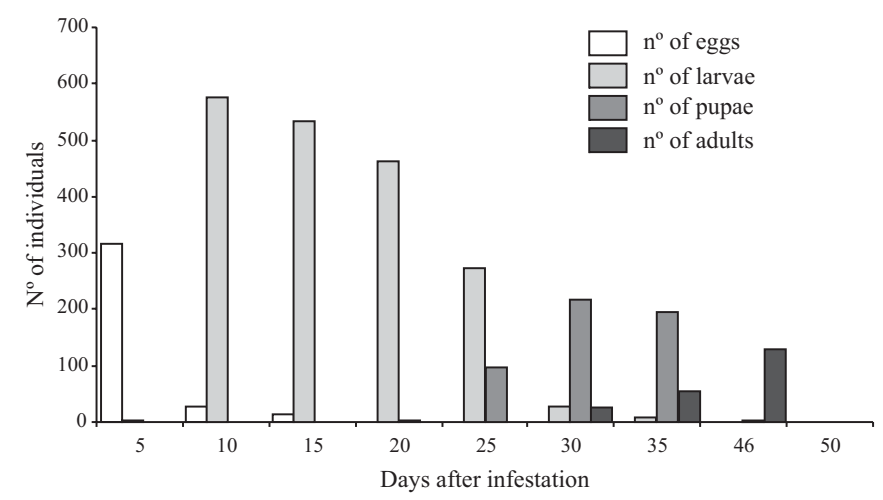

Fig. 1. Mean number of eggs, larvae, pupae and adults of Oryzaephilus surinamensis reared on milled wheat grain grade 20 , at $25 \pm 0.5^{\circ} \mathrm{C}$ and $65 \pm 5 \%$ RH. 
Table II. Mean number ( \pm standard deviation) of eggs of Oryzaephilus surinamensis reared on wheat kernels milled at different granulometry, at $25 \pm 0.5^{\circ} \mathrm{C}$ and $65 \pm 5 \% \mathrm{RH}$.

\begin{tabular}{lcccc}
\hline \multirow{2}{*}{ Diet } & \multicolumn{4}{c}{ Day of assessment after infestation } \\
\cline { 2 - 5 } & 5 & 10 & 15 & 20 \\
\hline Grade 5 & 0 & $41.0( \pm 22.19)$ & $3.5( \pm 1.9)$ & 0 \\
Grade 9 & 0 & $56.7( \pm 6.18)$ & $4.5( \pm 2.3)$ & $0.2( \pm 0.50)$ \\
Grade 11 & 0 & $25.2( \pm 6.65)$ & $4.5( \pm 3.10)$ & $0.2( \pm 0.50)$ \\
Grade 20 & $313.2( \pm 51.38)$ & $26.5( \pm 8.26)$ & $12.2( \pm 9.32)$ & $0.2( \pm 0.50)$ \\
Whole grain & $16.7( \pm 7.13)$ & $0.5( \pm 0.57)$ & 0 & 0 \\
\hline
\end{tabular}

Considering all treatments, the number of larvae was higher than the number of adults emerged, what can be justified by larval and pupal mortality caused by handling during assessment, besides natural mortality. Table I shows that the grade 20 wheat presented the highest number of larvae and adults, despite the low survival of larvae (34\%, representing about 572 individuals). The most plausible explanation is that the grains are broken in a granulometry that exposes the germ, but do not reduce it to particles too small to be fed on.

Despite the difficulty to visualize eggs and larvae on the grain grades 5,9 e 11, the number of larvae transformed into adults in these media were $73 \%, 48 \%$, and $58 \%$, respectively. Fleming (1988) also mentions the difficulty of rearing this species on different grades of milled wheat, especially on the fine ones because the media had a lot of flour in it.

Armstrong \& Howe (1963), rearing adults of $O$. surinamensis on four varieties of wheat in laboratory at $22.5^{\circ} \mathrm{C}$, observed high mortality when the insects fed only on the endosperm of broken grain, what reflects the difficulty of this species to grow in a medium without the appropriate grain milling and without the germ available, which contains high

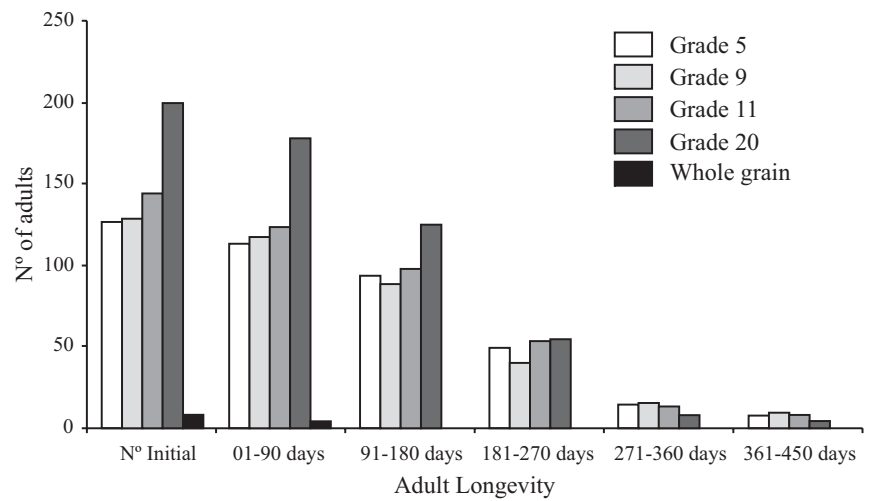

Fig. 2. Mean number of surviving adults of Oryzaephilus surinamensis on wheat kernels milled at different granulometry, in five trimesters of assessment, $25 \pm 0.5^{\circ} \mathrm{C}$ and $65 \pm 5 \% \mathrm{RH}$.

levels of lipids and vitamins (USDA 1998). O. surinamensis showed a tremendous increase in progeny production on 6mo maize previously infested by primary species or mechanically damaged kernels (Weston \& Rattlingourd 2000).

Biological Cycle. Based on the results from the rearing method above, the diet with wheat milled to grade 20 was chosen to determine the life cycle of $O$. surinamensis in order to obtain age standardized specimens.

Considering the mean number of eggs, $89 \%$ were obtained at the $5^{\text {th }}$ day after the adults were placed in the medium; $7.5 \%$ at the $10^{\text {th }}$ day, $3.45 \%$ at the $15^{\text {th }}$ day, and $0.05 \%$ at the $20^{\text {th }}$ day (Table II and Fig. 1). It means that the incubation period was up to five days and that is the period that yields the largest number of eggs. Howe (1956) and Aitken (1966) showed that O. surinamensis females can lay up to ten eggs per day during 265 days.

Table III. Mean number ( \pm standard deviation) of larvae of Oryzaephilus surinamensis reared on wheat kernels milled at different granulometry, at $25 \pm 0.5^{\circ} \mathrm{C}$ and $65 \pm 5 \% \mathrm{RH}$.

\begin{tabular}{|c|c|c|c|c|c|c|c|c|}
\hline \multirow{2}{*}{ Diet } & \multicolumn{8}{|c|}{ Day of assessment after infestation } \\
\hline & 5 & 10 & 15 & 20 & 25 & 30 & 35 & 46 \\
\hline Grade 5 & 0 & $34.7( \pm 25.47)$ & $135.2( \pm 22.12)$ & $172.2( \pm 41.01)$ & $124.2( \pm 14.08)$ & $5.0( \pm 4.32)$ & $1.2(1.25 \pm)$ & 0 \\
\hline Grade 9 & 0 & $171.5( \pm 32.90)$ & $267.5( \pm 84.01)$ & $218.7( \pm 27.43)$ & $163.2( \pm 27.88)$ & $3.5( \pm 1.73)$ & $1.2( \pm 0.5)$ & 0 \\
\hline Grade 11 & 0 & $248.0( \pm 42.13)$ & $233.7( \pm 38.72)$ & $219.5( \pm 33.45)$ & $145.7( \pm 26.80)$ & $2.0( \pm 0.81)$ & $0.5( \pm 1.00)$ & 0 \\
\hline Grade 20 & $2.5( \pm 2.08)$ & $571.7( \pm 76.93)$ & $533.2( \pm 85.54)$ & $462.5( \pm 110.86)$ & $271.2( \pm 60.21)$ & $23.5( \pm 19.50)$ & $7.7( \pm 4.92)$ & 0 \\
\hline Whole grain & $3.0( \pm 2.44)$ & $11.7( \pm 2.98)$ & $10.5( \pm 3.10)$ & $9.5( \pm 2.08)$ & $8.5( \pm 1.29)$ & $13.1( \pm 16.99)$ & $0.7( \pm 0.95)$ & 0 \\
\hline
\end{tabular}

Table IV. Mean number ( \pm standard deviation) of pupae of Oryzaephilus surinamensis reared on wheat kernels milled at different granulometry, at $25 \pm 0.5^{\circ} \mathrm{C}$ and $65 \pm 5 \% \mathrm{RH}$.

\begin{tabular}{lcccc}
\hline \multirow{2}{*}{ Diet } & \multicolumn{4}{c}{ Day of assessment after infestation } \\
\cline { 2 - 5 } & 20 & 25 & 30 & 35 \\
\hline Grade 5 & 0 & $6.0( \pm 3.36)$ & $60.2( \pm 7.93)$ & $75.7( \pm 18.00)$ \\
Grade 9 & $0.2( \pm 0.50)$ & $14.0( \pm 8.79)$ & $100.0( \pm 8.90)$ & $102.5( \pm 6.65)$ \\
Grade 11 & $0.5( \pm 0.57)$ & $20.5( \pm 1.7)$ & $128.0( \pm 15.47)$ & $118.7( \pm 23.30)$ \\
Grade 20 & $4.2( \pm 2.50)$ & $91.7( \pm 18.51)$ & $215.0( \pm 18.63)$ & $191.5( \pm 42.14)$ \\
Whole grain & 0 & $1.2( \pm 0.95)$ & $6.0( \pm 1.41)$ & $8.0( \pm 1.63)$ \\
\hline
\end{tabular}

Table V. Mean number ( \pm standard deviation) of adults of Oryzaephilus surinamensis reared on wheat kernels milled at different granulometry, at $25 \pm 0.5^{\circ} \mathrm{C}$ and $65 \pm 5 \% \mathrm{RH}$.

\begin{tabular}{lccc}
\hline \multirow{2}{*}{ Diet } & \multicolumn{3}{c}{ Day of assessment after infestation } \\
\cline { 2 - 4 } & 30 & 35 & 46 \\
\hline Grade 5 & $2.2( \pm 2.06)$ & $18.7( \pm 8.01)$ & $105.2( \pm 24.79)$ \\
Grade 9 & $4.0( \pm 2.70)$ & $28.7( \pm 6.39)$ & $96.0( \pm 19.61)$ \\
Grade 11 & $4.2( \pm 1.70)$ & $35.5( \pm 6.45)$ & $104.0( \pm 27.89)$ \\
Grade 20 & $21.2( \pm 6.39)$ & $52.0( \pm 23.16)$ & $126.2( \pm 36.06)$ \\
Whole grain & $0.7( \pm 0.95)$ & $0.2( \pm 0.50)$ & $6.7( \pm 1.50)$ \\
\hline
\end{tabular}


Table VI. Mean number of dead adults ( \pm standard deviation) of Oryzaephilus surinamensis in wheat kernels milled at different granulometry, in five trimesters of assessment, at $25 \pm 0.5^{\circ} \mathrm{C}$ and $65 \pm 5 \% \mathrm{RH}$.

\begin{tabular}{lcccccc}
\hline Diets & $\mathrm{N}^{\circ}$ Adults & $1-90$ days & $91-180$ days & $181-270$ days & $271-360$ days & $361-450$ days \\
\hline Grade 5 & 126.25 & $13.5( \pm 9.25) \mathrm{ab}$ & $19.00( \pm 4.69) \mathrm{b}$ & $44.00( \pm 18.38) \mathrm{a}$ & $35.50( \pm 6.75) \mathrm{ab}$ & $7.50( \pm 3.31) \mathrm{a}$ \\
Grade 9 & 128.75 & $11.25( \pm 5.31) \mathrm{ab}$ & $29.00( \pm 6.48) \mathrm{ab}$ & $48.25( \pm 19.87) \mathrm{a}$ & $25.25( \pm 5.73) \mathrm{b}$ & $6.25( \pm 2.21) \mathrm{a}$ \\
Grade 11 & 143.75 & $20.25( \pm 0.5) \mathrm{a}$ & $26.00( \pm 4.69) \mathrm{b}$ & $43.50( \pm 16.98) \mathrm{a}$ & $41.00( \pm 13.95) \mathrm{ab}$ & $5.50( \pm 1.00) \mathrm{a}$ \\
Grade 20 & 199.50 & $22.00( \pm 7.43) \mathrm{a}$ & $54.50( \pm 14.36) \mathrm{a}$ & $68.50( \pm 26.33) \mathrm{a}$ & $47.25( \pm 7.76) \mathrm{a}$ & $3.50( \pm 1.00) \mathrm{a}$ \\
Whole grain & 7.75 & $4.00( \pm 1.63) \mathrm{b}$ & $3.75( \pm 1.25) \mathrm{c}$ & 0 & 0 & 0 \\
\hline
\end{tabular}

Mean numbers followed by the same letter, within the same column, are not significantly different $(\mathrm{P}>0.05)$ by Tukey test.

* Mean number of adults evaluated.

The percentage of larvae in the medium was: $0.1 \%$ at the $5^{\text {th }}$ day after infestation; $30.5 \%$ at the $10^{\text {th }}$ day; $28.5 \%$ at the $15^{\text {th }}$ day; $24.7 \%$ at the $20^{\text {th }}$ day; $14.5 \%$ at the $25^{\text {th }}$ day; $1.3 \%$ at the $30^{\text {th }}$ day, and $0.4 \%$ at the $35^{\text {th }}$ day. From the $10^{\text {th }}$ to the $20^{\text {th }}$ day after adult infestation was the period that yielded the largest number of larvae (Table III and Fig. 1).

The first pupae were detected about three weeks after the detection of the first larvae: $1 \%$ at the $20^{\text {th }}$ day; $18 \%$ at the $25^{\text {th }}$ day; $43 \%$ at the $30^{\text {th }}$ day; and $38 \%$ at the $35^{\text {th }}$ day. It means that from the $30^{\text {th }}$ to the $35^{\text {th }}$ days after adult infestation is the period that yields the largest number of pupae (Table IV and Fig. 1).

Adults started to emerge at the $30^{\text {th }}$ day, when $10.6 \%$ insects were counted; they were $26 \%$ at the $35^{\text {th }}$, and $63.4 \%$ at the 46 th day, which was the period after infestation that yielded the largest number of adults (Table V and Fig. 1). The mean total period for development from egg to adult was about 35 days.

Jacob \& Fleming (1989), studying some biological aspects of $O$. surinamensis, found that egg incubation was 6.6 days, larval period was 21.5 days, and pupae took 9 days to complete development; the total period was 37 days from egg to adult, what was similar to the results obtained from this research. Similar results for the total biological cycle were found by Beckett \& Evans (1994) and Aitken (1966).

It is well known and should be taken into account when rearing $O$. surinamensis that the conditions of storage, as well as the kind of food, affect directly the developmental period of each stage. It was also observed that culturing $O$. surinamensis under the described conditions, transferring the parental adults after 10 days and replacing the media when population builds up, there will be enough insects of each stage for various laboratory bioassays.

Longevity. Adults of $O$. surinamensis survived, at $25 \pm 0.5^{\circ} \mathrm{C}$ and $65 \pm 5 \% \mathrm{RH}$, up to 450 days in wheat kernels ground at different grades, except in whole grain, where the insects survived only up to 60 days (Table VI and Fig. 2). These results confirm again that whole grain is not adequate for multiplication and survival of this species.

The highest adult mortality was observed at the third trimester of assessment, about 270 days after infestation, with mean mortality ranging from 30 to $37 \%$ (Table VI and Fig. 2). Since there was no statistical difference among diets, between the third and fifth trimesters of evaluation, it is possible to infer that the different diets didn't play a role on longevity of
O. surinamensis. The statistical difference observed between the first, second and fourth trimesters were possibly due to the different insect number placed on each diet (Table VI).

\section{CONCLUSIONS}

It was concluded that wheat grain milled at grade 20 yields the largest number of progeny of $O$. surinamensis; the largest number of eggs can be harvested by the $5^{\text {th }}$ day after adult infestation, larvae by the $10^{\text {th }}$, pupae by the $30^{\text {th }}$, and adults by the $46^{\text {th }}$ day at $25 \pm 0.5^{\circ} \mathrm{C}$ and $65 \pm 5 \%$ RH. Different milling grades of wheat kernels do not affect adult longevity.

\section{REFERENCES}

Aitken, A. D. 1966. A strain of small Oryzaephilus surinamensis (L.) (Coleoptera, Silvanidae) from the Far East. Journal of Stored Products Research 2: 45-55.

Armstrong, M. T. \& R.W. Howe. 1963. The saw-toothed grain beetle (Oryzaephilus surinamensis) in home-grown grain. Journal of Agricultural Engineering Research 8: 256-261.

Beckett, S. J. \& D. E. Evans. 1994. The demography of Oryzaephilus surinamensis (L.) (Coleoptera: Silvanidae) on Kibbled wheat. Journal of Stored Products Research 30: 121-137.

Champ, B. R. \& C. E. Dyte. 1976. Informe de la prospeccion mundial de la FAO sobre susceptibilidad a los inseticidas de las plagas de granos almacenados. Roma, $356 \mathrm{p}$.

Collins, P. J.; J. C. Mulder \& D. Wilson. 1989. Variation in life history parameters of Oryzaephilus surinamensis (L.) (Coleoptera: Silvanidae). Journal of Stored Products Research 25: $193-$ 199.

Fleming, D. A. 1988. The influence of wheat kernel damage upon the development and producvity of Oryzaephilus surinamensis (L.) (Coleoptera: Silvanidae). Journal of Stored Products Research 24: 233-236.

Flinn, P. \& K. Friesen. 2007. Host and parasitoid rearing. Available at the site http://ars.usda.gov/Research/docs.htm?docid=12885.

Fraenkel, G. \& M. Blewett. 1943. The natural foods and the food requirements of several species of stored products insects. Transactions of the Royal Entomological Society of London 93: 457-490.

Greening, H. G.; B. E. Wallbank \& F. I. Attia. 1974. Resistance to malathion and dichlorvos in stored-product insects in New South Wales. Proceedings of the First International Working Conference on Stored Product Entomology, Savannah, Georgia, USA, October 1974, 608-617.

Heather, N. W. \& D. Wilson. 1983. Resistance to fenitrothion in Oryzaephilus surinamensis (L.) (Coleoptera: Silvanidae) in Queensland. Journal of the Australian Entomological Society 22: 210.

Highland, H. A. 1991. Protecting packages against insects, p. 345- 
350. In: J. R. Gorham (ed.), Ecology and Management of FoodIndustry Pests, FDA Technical Bulletin 4. Association of Official Analytical Chemists, Arlington, Virginia.

Howe, R. W. 1956. The biology of the two common storage species of Oryzaephilus (Coleoptera, Cucujidae). Annals of Applied Biology 44: 341-355.

Howe, R. W. 1965. A summary of estimates of optimal and minimal conditions for population increase of some stored products insects. Journal of Stored Products Research 1: 177-184.

Howe, R. W. 1973. Loss of viability of seed in storage attributable to infestations of insects and mites. Seed Science \& Technology 1: $563-586$.

Jacob, T. A. \& D. A. Fleming. 1989. The difference in the development period and mortality of some field strains of Oryzaephilus surinamensis (L.) at constant temperatures (Coleoptera: Silvanidae). Journal of Stored Products Research 25: 73-76.

LeCato, G. L. \& T. L. McCray. 1973. Multiplication of Oryzaephilus spp. and Tribolium spp. on 20 natural product diets. Environmental Entomology 2: 176-179.

Lorini, I. 2005. Manual técnico para o manejo integrado de pragas de grãos de cereais armazenados. Embrapa Trigo. Passo Fundo, RS. 80 p.

Mason, P. L. 1996. Population biology of the saw-toothed grain beetle, Oryzaephilus surinamensis (Coleoptera: Silvanidae), in an experimental model of a fabric treatment. Bulletin of Entomological Research 86: 377-385.

Mathlein, R. 1971. Rearing experiments with Oryzaephilus surinamensis L. and Cryptolestes ferrugineus Steph. on grain. National Swedish Institute Plant Protection Contributions 15: $187-203$.

Mowery, S. V.; M. A. Mullen; J. F. Campbell \& A. B. Broce. 2002. Mechanisms underlying sawtoothed grain beetle (Oryzaephilus surinamensis [L.]) (Coleoptera: Silvanidae) infestation of consumer food packaging materials. Journal of Economic Entomology 95: $1333-1336$.
Nakajima, S.; K. Sugawara; T. Takeda; M. Tateishi; A. Okamura; J. Iwasa \& N. Baba. 1996. Arrestants to Oryzaephilus surinamensis L. from wheat flour infested by the same weevil. Bioscience, Biotechnology and Biochemistry 60: 1546-1547.

Pricket, A. J.; J. Muggleton \& J. A. Llewellin. 1990. Insecticide resistance in populations of Oryzaephilus surinamensis and Cryptolestes ferrugineus from grain stores in England and Wales. Brighton Crop Protection Conference-Pests and Diseases 3: 11891194.

Sinha, R. N. 1971. Multiplication of some stored-product insects on varieties of wheat, oats, and barley. Journal of Economic Entomology 64: 98-102.

Thomas, E. L. \& H. H. Shepard. 1940. The influence of temperature, moisture, and food upon the development and survival of the sawtoothed grain beetle. Journal of Agricultural Research 60: $605-615$.

Turney, H. A. 1957. Some effects of cracked grain on the reproduction of the saw-toothed grain beetle. Journal of Kansas Entomological Society 30: 6-8.

USDA [United States Department of Agriculture, Agricultural Research Service]. 1998. Nutrient database for standard reference, release 12: Nutrient data laboratory home page (http://www.nal.usda.gov/ fnic/foodcomp).

Wallbank, B. E. \& P. J. Collins. 2003. Recent changes in resistance to grain protectants in eastern Australia, p. 66-70. In: E. J. Wright, M. C. Webb \& E. Highley (eds.). Stored grain in Australia 2003. Proceedings of the Australian Postharvest Technical Conference, Canberra, 25-27 June 2003.

Weston, P. A. \& P. L. Rattlingourd. 2000. Progeny production by Tribolium castaneum (Coleoptera: Tenebrionidae) and Oryzaephilus surinamensis (Coleoptera: Silvanidae) on maize previously infested by Sitotroga cerealella (Lepidoptera: Gelechiidae). Journal of Economic Entomology 93: 533-536. 